\title{
消波型高基混成堤の越波特性 \\ Wave Overtopping Characteristics of High Mound Composite Seawalls
}

高橋重堆*·下迫健一郎*·斉藤祐一**·三浦裕信***•姜 閏求*

Shigeo Takahashi, Kenichiro Shimosako, Yuichi Saitoh, Hironobu Miura, Yoon-Koo Kang

\begin{abstract}
A series of model experiments were conducted to investigate wave overtopping characteristics of high mound composite seawalls with slit type superstructures. This type seawall is economical and suitable especially in a bay with a large tidal range. Its wave overtopping was found to be smaller than that of rubble-mound-type seawalls. Several types of rubble foundation with different kinds of armor blocks, and modified superstructures were also tested. The slit type superstructure with a slit upper beam was found to be most effective to reduce wave overtopping.

Keywords: Wave overtopping, Seawall, Low-crest seawall, High mound breakwater
\end{abstract}

\section{1. はじめに}

防波護岸の越波流量を小さくする最も効果的な方法は天端を高くすることである。しかし、空港用の護岸などで は、航空機離着陸時の高さ制限や埋め立て地の地盤高さの関係で、天端をあまり高くできない場合も多い。その ため、天端をできるだけ低く抑え、なおかつ越波量を低減させる必要がある。

このような低天端型護岸に関する研究は、これまでに合田・岸良 ${ }^{1)}$ 、高山ら ${ }^{2)}$ 、谷本ら ${ }^{3)}$ などによって行われてお り、消波ブロックにより波を減衰させる方法、直立消波ケーソンを用いる方法、パラペットを後退させる方法などが 知られている。著者らも、これらの方法を含むいくつかの方法について検討を行い、1995 年のこの論文集 ${ }^{4}$ に発 表している。そこでは、ケーソン天端にブロックを並べることによって越波を大きく軽減できることなどを示している。 また、通常の混成堤よりもマウンドの高い高基混成堤についても検討の対象とし、直立部に消波ケーソンを用い た高基混成堤を越波低減効果が高い低天端堤構造として有力であることを示している。

通常の傾斜堤 (消波ブロック被覆堤) で天端を低くする場合、前面勾配を緩やかにした緩傾斜堤を用いる方法 が有効である。ただし、緩傾斜にした分だけ断面が大きくなり経済性は悪くなる。図ー1は、今回の研究で対象と した消波型高基混成堤と緩傾斜堤の断面を示したものである。高基混成堤は高マウンドの上に比較的小さい直 立部を有する傾斜堤に近い混成堤で、環境への効果索考慮して前面勾配は $1: 3$ と緩傾斜となっている。直立部 はスリット壁と遊水部を持つ消波構造である。天端面までブロックを高く積み上げる緩傾斜堤に比べて、断面が小 さく経済的であり、景観上も優れている。図では緩傾斜堤と同じ天端高にしているが、越波量を低減できれば天 端高をさらに下げることができ、より有利な断 面となる。

従来、高基混成堤は衝撃砕波力が作用す ることがあるため危険な構造とされていた。し 加、著者らは高基混成堤の波力特性に関 寸る研究を行い、直立部に消波構造を用い、 マウンド前肩幅を適切にとることによって波力 が著しく低隇し、耐波安定性が高いことも明ら かにしている5゙。図一2は、直立型と消波型に おける波の作用状況の違いを模式的に示し たもので、波圧波形の例もあわせて示してい る。図からもわかるように、消波型とすることに よって波力だけでなく波の打ち上げ高さも大 きく低減する。

本研究注、このような消波型高基混成堤 に関して、越波特性からみた最適断面形状を 明らかにすることを目的として、実験的検討を 行ったものである。実験では、まずマウンド前

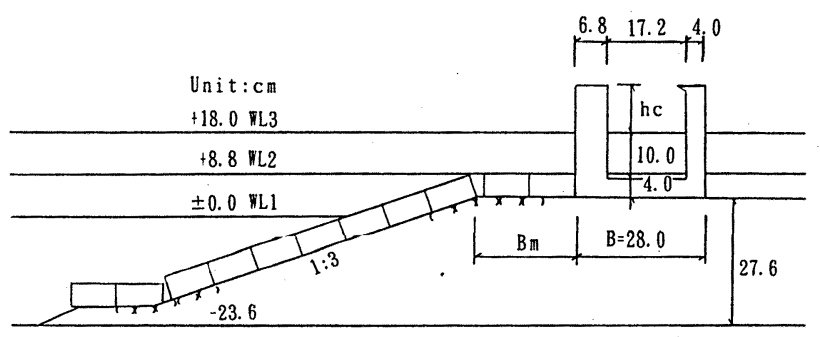

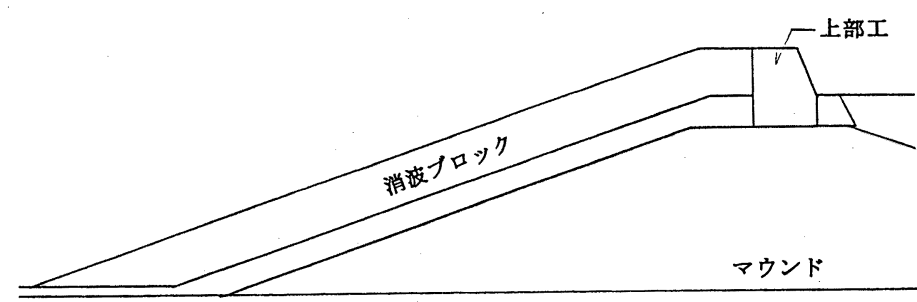

図 -1 消波型高基混成堤と緩傾斜堤の断面図

\footnotetext{
* 正会員 運輸省港湾技術研究所水工部而波研究室 (239 横須賀市長瀬 3-1-1)

** 運輸省第三港湾建設局

*** 運輸省第一港湾建設局秋田港湾工事事務所
} 
肩幅および直立部の天端高を変えた場合の、越 波特性の変化について検討し、図に示した緩傾 斜堤との比較も行った。また、越波低減効果をさ らに高めると同時に、経済性、施工性、あるいは 環境への効果についても向上をはかるため、マ ウンド形状および直立部の形状を改良した断面 についても実験を行っている。

\section{2. 実験の方法}

\section{1 実験水路および標準断面}

実験注、小型造波水路 (長さ $35 \mathrm{~m}$ 、幅 $0.5 \mathrm{~m}$ 、高 さ $1 \mathrm{~m}$ )で実施した。対象とした堤体の標準断面 は、図ー1に示したとおりである。直立部のスリッ 卜壁は直径 $68 \mathrm{~mm}$ の円柱型スリットで、スリットの 中心間距離は $10 \mathrm{~cm}$ であり、前面からみた見かけ の開口率は $32 \%$ となる。直立部の天端高 $h_{\mathrm{C}}$ は $8,10,12 \mathrm{~cm}$ の 3 種類、マウンド前有幅 $B_{\mathrm{m}}$ は $0,16,22,36 \mathrm{~cm}$ の 種類に変化させており、マウン ドは張りブロックで被覆している。また、直立部後 壁にパラペットを付けて越波量の低減をはかった ものを標準断面の一つと考え、スリット円柱の前 半分と後壁の上面に薄い亜鉛板を用いた幅 $5 \mathrm{~mm}$ または $10 \mathrm{~mm}$ の水平な張り出しを付けた場 合と、パラペットなしの場合の比較も行った。さら に、比較のために、同じ前面勾配の緩傾斜堤に
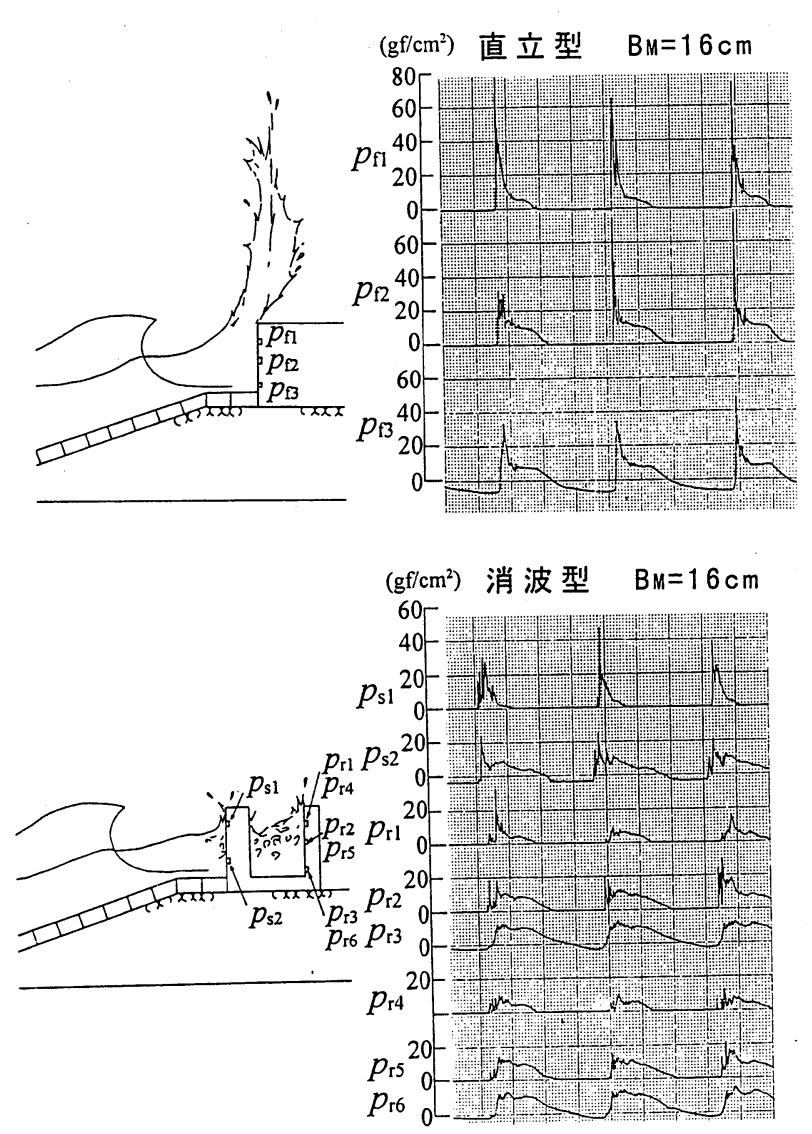

図-2 波の作用状況

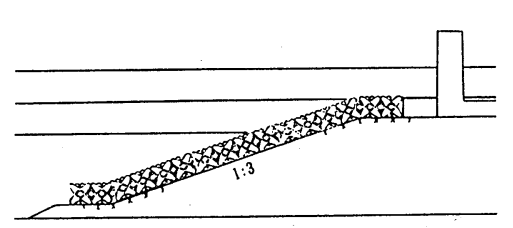

(a) 標準型(一層乱積み被覆)

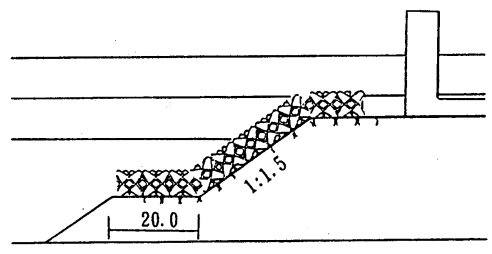

（d）小段縮小型(一層乱積み被覆）

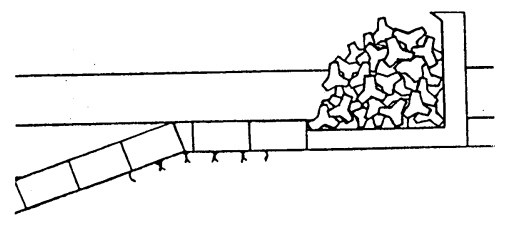

（g）小段ブロック被覆型

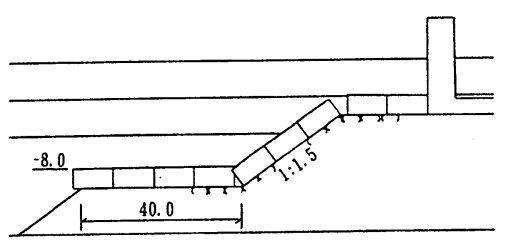

(b) 小段型

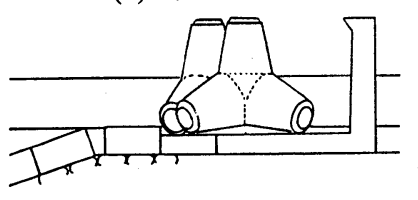

(e) 大型ブロック型 (一列)

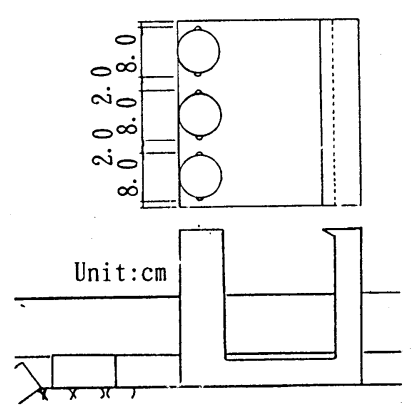

(h) 標準型 (開口率 20\%)

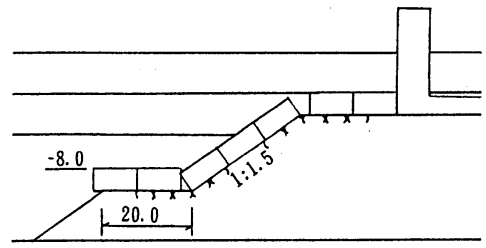

(c) 小段縮小型

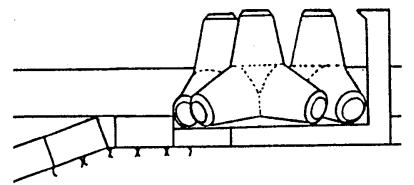

(f) 大型ブロック型 (ニ列)
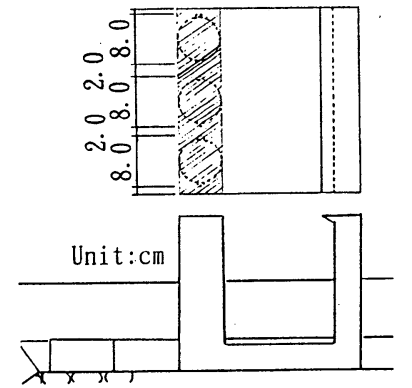

(i) 標準型上部梁付き(開口率 20\%)

図-3 消波型高基混成堤改良断面 
ついても実験を行っている。なお、この標準断面は内湾域で比較的水深が浅く、しかも設計潮位の大きい場所を 対象にしており、高基混成堤はこのような場所に適していると考えている。図ー1にはWL1〜3の3つの潮位が示 してあるが、これらはそれぞれ L.W.L. H.W.L.、H.H.W.L.に相当している。本構造の場合、L.W.L.および H.W.L.時の越波はほとんど問題にならないため、H.H.W.L.に相当するWL3 に対してのみ実験を行った。模型 縮尺は現地の $1 / 25$ 程度を想定しており、この場合、水深は $5.9 \mathrm{~m}$ 、潮位は H.H.W.L.時で $+4.5 \mathrm{~m}$ 、天端高は H.H.W.L.上 $2 \sim 3 \mathrm{~m}$ となる。なお、今回の研究では基本的には図－1の断面を対象としているが、他の条件でも 適用できるよう、できるだけ一般的な越波特性を求めることを目的としている。

\section{2 改良断面}

図一3は、改良型の堤体形状を示している。以下にその特徵と目的を示す。

(a)はマウンド被覆ブロックとして、張りブロックの代わりに一層乱積みブロックを用いた断面である。これは、空 隙の大きなブロックを用い、生物にとってよりよい育成環境を造ろうとするものであり、また乱積みであることによっ てマウンドの均しの軽減を考えている。

(b)〜 (d)はマウンドの形状を変えたもので、(b)は、小段を設けて環境面の向上を図ろうとする断面、(c)は(b)を より経済的にするため小段を短くした断面、(d)は(c)の被覆ブロックを一層乱積みブロックに変えた断面である。

(e)〜 (g) は直立部の形状を変えたもので、施工面方らスリット部を消波ブロックで置き換えたものである。(e)、(f) は円筒型前面スリットの代わりに大型の消波ブロックをおいた断面で、(e)がブロックー列並び、(f)が二列並びで ある。(g)はスリットの代わりに小型の消波ブロックで後壁を被覆した断面である。

(h)、(i)はスリット壁の構造を変えて越波量を低減し、波の打ち上げを減らすことを目的とした構造であり、(h) は 円柱の側面に半円柱型の張り出し部を設けて開口率を $20 \%$ とした断面で、(i)は(h)の断面にさらに円柱の上部を 薄い亜鉛板でつなぎ、打ち上げを減らすための上部梁とした断面である。

\section{3 実験波および計測方法}

実験波は、主として周期 $1.44 \mathrm{~s}$ (現地換算 $7.2 \mathrm{~s}$ ) の規則波および不規則波を用いており、波高は 規則波で $H=14 \sim 26 \mathrm{~cm}$ 、不規則波で $H_{1 / 3}=6$ $\sim 19 \mathrm{~cm}$ 程度である。なお、設計波高としては $H_{1}$ ${ }_{3}=16 \mathrm{~cm}$ (現地換算で $\left.4.0 \mathrm{~m}\right)$ を想定している。 計測時間は規則波では約 16 秒間 (11 波)、不規 則波では約 4 分間(約 190 波)である。不規則波 については、波群の異なる3 種類の波を作用さ せ、実験結果は3 波群の平均值を用いて整理し ている。不規則波のスペクトルは、修正ブレットシ ユナイダー・光易型を目標とした。

実験では、越波流量の測定のほか、規則波の 場合は打ち上げ高さ、不規則波の場合は反射率 についても測定を行った。打ち上げ高さは、波の 実質部分と飛沫の両方について調べている。

\section{3. 標準断面の越波特性}

\section{1 マウンド前肩幅と越波特性}

高基混成堤では、ある程度以上の波高の波は すべてマウンド斜面あるいはマウンド上で砕波す る。したがって、マウンド法有から直立部までの

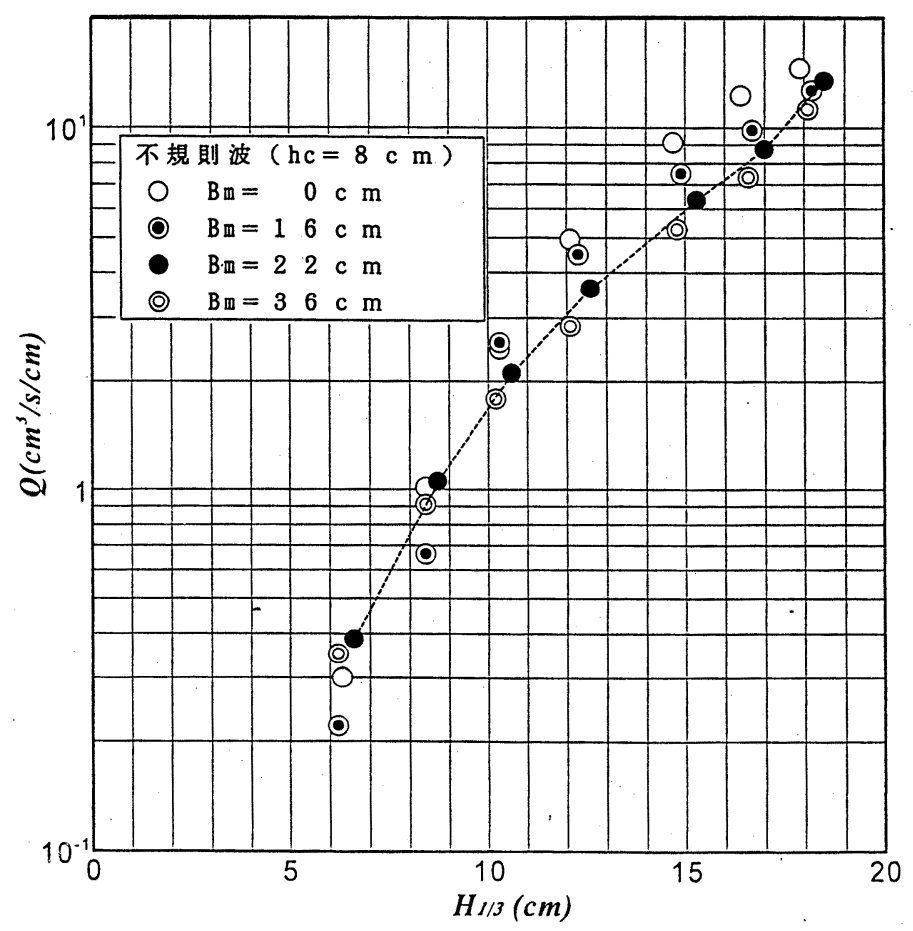

図-4 マウンド前肩幅と越波流量

距離が遠くなるほど、波力が減少することが明らかになっている。越波についても、波力と同様に距離が遠くなる と、同じ天端高でも越波流量が少なくなることが予想される。そこで、まずマウンド前肩幅と越波流量の関係につ いて調べた。

図一4は、不規則波による実験結果を示したもので、横軸に入射波の有義波高 $H_{1 / 3}$ をとり、縦軸に単位幅、単 位時間当たりの平均越波流量Qをとっている。なお、できるだけ測定誤差を少なくするために、天端高 $h_{\mathrm{C}}$ は最も 低い $8 \mathrm{~cm}$ とし、越波量の多い条件で比較した。データには多少のばらつきがみられるが、全体的にはマウンド前 有幅 $B_{\mathrm{m}}$ が長いほど越波流量は小さくなっている。すなわち、越波特性からみると、マウンド前肩幅を長くとるほう 
が有利であることがわかる。ただし、前肩幅を長く とると、その分マウンド断面が大きくなり、コストが 高くなること、また、 $B_{\mathrm{m}}$ が $22 \mathrm{~cm}$ のケースと $36 \mathrm{~cm}$ のケースでは越波流量にそれほど大きな差はな いことなどを考慮し、以下の実験については $B_{\mathrm{m}}$ $=22 \mathrm{~cm}$ を標準として実施することとした。

なお、波力特性に関する既往の実験結果 ${ }^{5)} に$ よると、高基混成堤として直立部に㗢く波力を十 分に低減させるためには、 $B_{\mathrm{m}} / L>0.05 、 d / h<$ 0.25 とする必要がある。今回の断面は、 $B_{\mathrm{m}}=$ $22 \mathrm{~cm}$ のとき $B_{\mathrm{m}} / L=0.087$ 、H.H.W.L.のとき $d / h$ $=0.221$ であり、これらの条件を満たしている。

\section{2 天端高と越波流量}

図一 5 は、種々の天端高における消波型高基 混成堤と緩傾斜堤について、不規則波の場合の 越波流量を比較したものである。高基混成堤に ついては $B_{\mathrm{m}}=22 \mathrm{~cm}$ であり、円筒スリットの前半 分および後壁の上面にパラペットを設けた場合 の結果についても示している。パラペットありの 場合、パラペットなしに比べて越波流量が低減し ており、特に波高が小さい場合にその割合が顕

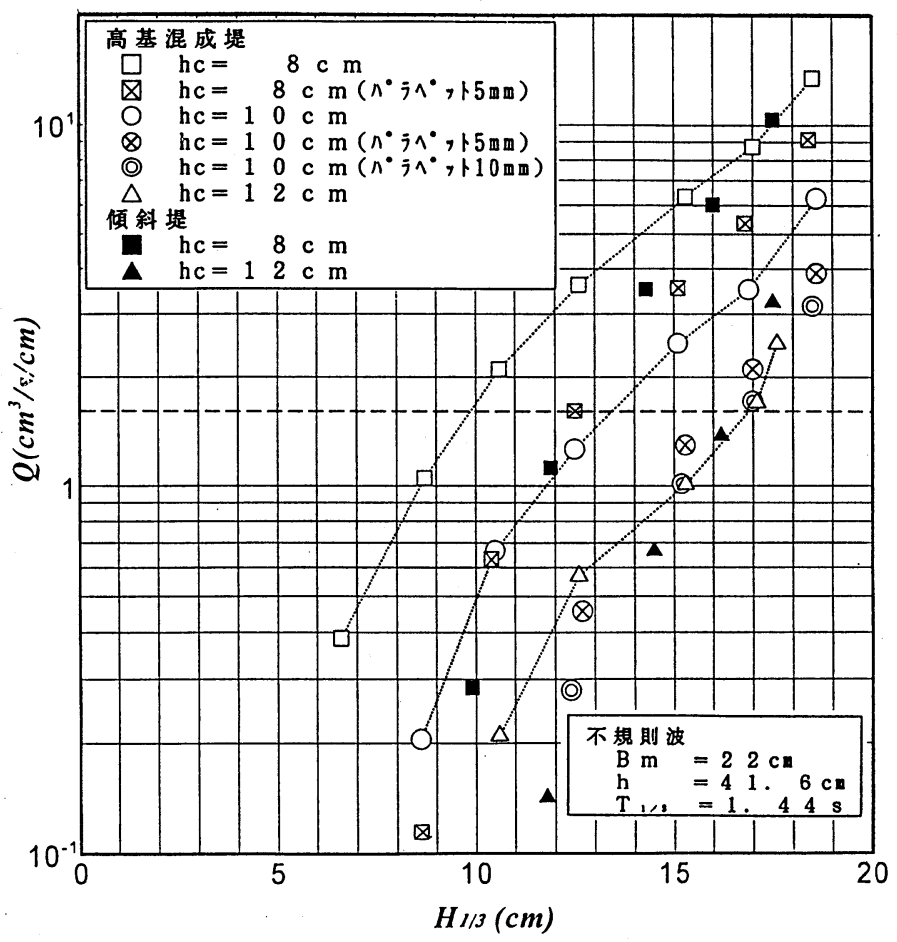

図 -5 天端高と越波流量 著である。 $h_{\mathrm{C}}=10 \mathrm{~cm}$ の場合についてパラペット $5 \mathrm{~mm}$ のケースと $10 \mathrm{~mm}$ のケースを比較すると、 $10 \mathrm{~mm}$ のほうが越 波流量の低減の割合が大きいが、波高が大きくなるにつれてその差は小さくなっている。

緩傾斜堤と高基混成堤の越波流量を比較すると、全体的に波高が小さいときは緩傾斜堤のほうが越波が少な いが、波高が大きくなると高基混成堤のほうが越波が少なくなる傾向がみられる。これは、緩傾斜堤の場合、波高 が小さいらちは斜面での波の減衰が大きいためあまり越波しないものの、波高が大きくなると波が斜面を遡上する ようにして越波するため、遊水室後壁によってある程度の波を反射する高基混成堤よりも越波流量が大きくなるた めと考えられる。

現地の護岸における許容越波流量は、背後地の重要怢などによっても異なるが、一つの目安として $0.02 \mathrm{~m}^{3} / \mathrm{s} / \mathrm{m}$ といら值が考えられる。今回の実験に当てはめると、模型スケールで $1.6 \mathrm{~cm}^{3} / \mathrm{s} / \mathrm{cm}$ であり、図中には この值を破線で示している。仮に設計波高をH $1 / 3=16 \mathrm{~cm}$ (現地換算で $4 \mathrm{~m}$ ) とすれば、緩傾斜堤 の場合、 $h_{\mathrm{C}}=12 \mathrm{~cm}$ のとき越波流量は許容值より もわずかに小さくなる。一方、高基混成堤の場合、 パラペットなしだと $h_{\mathrm{C}}=12 \mathrm{~cm}$ のとき緩傾斜堤の $h$ $c=12 \mathrm{~cm}$ とほとんど同じであるが、パラペット付き だと $h_{\mathrm{C}}=10 \mathrm{~cm}$ でもほぼ許容越波流量となる。

既往の研究によれば、上述の設計条件におい て許容越波流量を満たす通常の傾斜堤 (前面勾 配 $1: 4 / 3$ )の天端高は、 $15.6 \mathrm{~cm}$ (現地換算で $3.9 \mathrm{~m})$ である。この結果を用いて、通常の傾斜堤 の天端高を1としたとき、許容越波流量を満たす 緩傾斜堤の天端高を求めると 0.77 となる。これを 換算天端高係数 $\beta$ *と呼ぶ。 $5 \mathrm{~mm}$ のパラペット付 き高基混成堤の場合、換算天端高係数 $\beta$ * は 0.66 となり、傾斜堤に比べて天端高を約 $2 / 3$ に 下げられることがわかる。また、このときの相対天 端高 $h_{\mathrm{C}} / H_{1 / 3}$ の值は、傾斜堤、緩傾斜堤、高基 混成堤でそれぞれ $0.98 、 0.75 、 0.64$ となる。

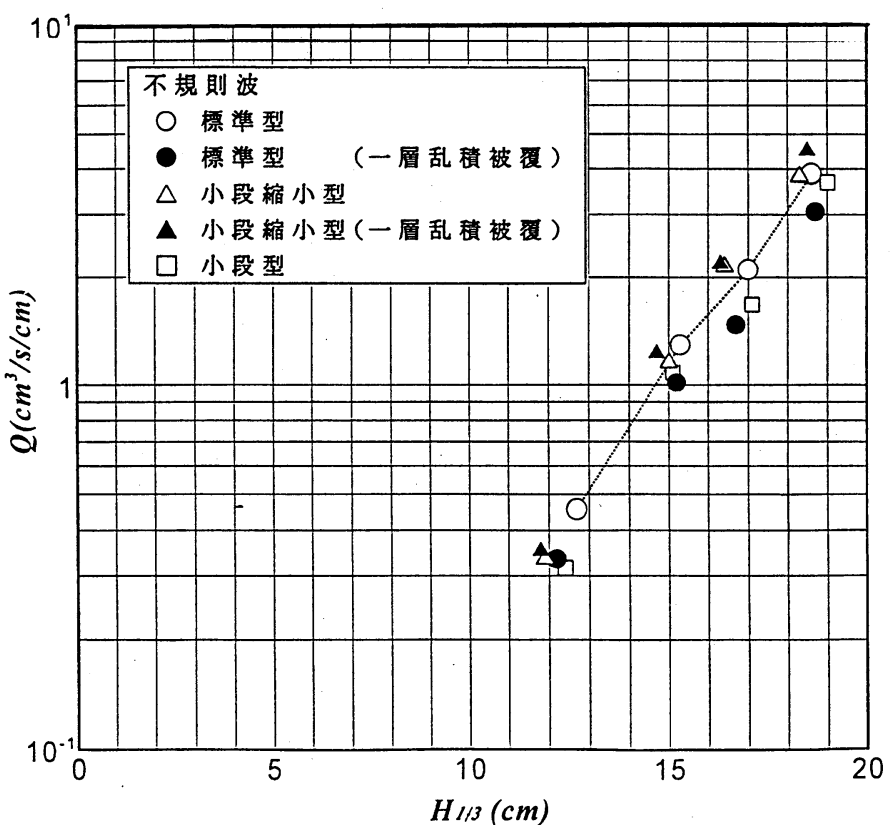

図-6 マウンド改良型の越波流量 


\section{4. 改良断面の越波特性}

\section{1 マウンド形状と越波特性}

越波流量および打ち上げ高さをより低減させるとともに、経済性、施工性、環境への効果も向上させるために、 標準断面に対していくつかの改良断面を考案し、実験を行った。まず、環境への効果等を考慮して、マウンド形 状の改良を行った。改良断面についてはすでに図ー3(a)〜 (d)に示したとおりである。なお、これらの改良断面お よび比較の対象とした標準断面は、すべて $5 \mathrm{~mm}$ のバラペットを付けている。

図ー6は、マウンド形状の違いによる越波流量の変化を示したものである。越波流量は、標準型に比べて小段 型はやや小さく、小段縮小型はやや大きい傾向があるものの、全体的にみるとこれらの差は非常に小さく、マウン ド形状の影響による越波流量の変化はほとんど ないと考えてよい。

これらの結果から、今回行った実験範囲では、 マウンド形状を変えても越波特性にあまり大きな 変化はなく、マウンド形状の改良による越波特性 の向上はあまり期待できないことがわかる。

\section{2 直立部の形状と越波特性}

3.2 において、直立部にパラペットを設けること により越波特性を改善できることを明らかにした。 ここでは、さらに越波流量および打ち上げ高さを 低減させるために、直立部の形状を改良して実 験を行った。改良型の形状については、図ー3 (e)〜 (i)に示したとおりである。なお、これらの改 良断面についても、すべて $5 \mathrm{~mm}$ のパラペットを 付けている。

図一 7 は、直立部の形状の違いによる越波流 量の変化を示したものである。参考のために標 準型の $h_{\mathrm{C}}=8 \mathrm{~cm}$ の結果も併せて示している。こ れ以外については、すべて $h_{\mathrm{C}}=10 \mathrm{~cm}$ である。まず、 標準型の開口率 $20 \%$ のケースとスリットの代わりに大 型ブロックを設置したケースについては、いずれも標 準型とあまり大きな違いはない。また、スリットの代わり に小型ブロックで後壁を被覆したケースについては、 逆に越波流量が増加し、標準型の $h_{\mathrm{C}}=8 \mathrm{~cm}$ のケース とほぼ同じとなっている。これに対し、開口率 $20 \%$ でス リット上面に梁を設けたケースでは、越波流量が著しく 減少している。これは、上部梁によって水塊の上向き の運動がおさえられるためである。このケースの換算 天端高係数 $\beta *$ * 0.54 であり、天端高を通常の傾斜 堤の約半分に下げられることがわかる。また、このとき の相対天端高 $h_{\mathrm{C}} / H_{1 / 3}$ の值は 0.53 となる。この值は、 護岸の天端高であるにもかかわらず、通常の防波堤に おける $h_{\mathrm{C}} / H_{1 / 3}$ の值 0.6 よりも小さく、きわめて低天端 であることがわかる。

\section{5. 波の打ち上げ高さ}

図一8注、種々の条件における波の打ち上げ高さ $\eta$, を示したもので、高基混成堤についてはいずれも $B_{\mathrm{m}}$ $=22 \mathrm{~cm}$ で、 $5 \mathrm{~mm}$ のパラペット付きで、標準型の $h_{\mathrm{C}}=$ $8 \mathrm{~cm}$ のケース以外はすべて $h_{\mathrm{C}}=10 \mathrm{~cm}$ である。なお、 打ち上げ高さは天端面を 0 として定義している。まず 高基混成堤の標準型と改良型について比較すると、

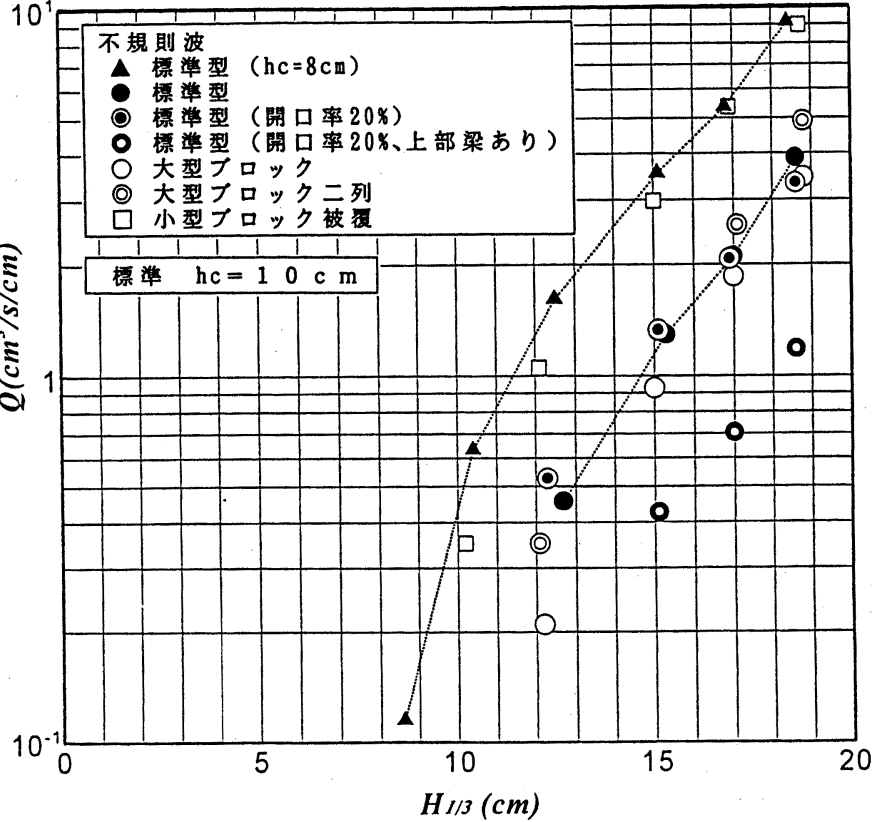

図 -7 直立部改良型の越波流量

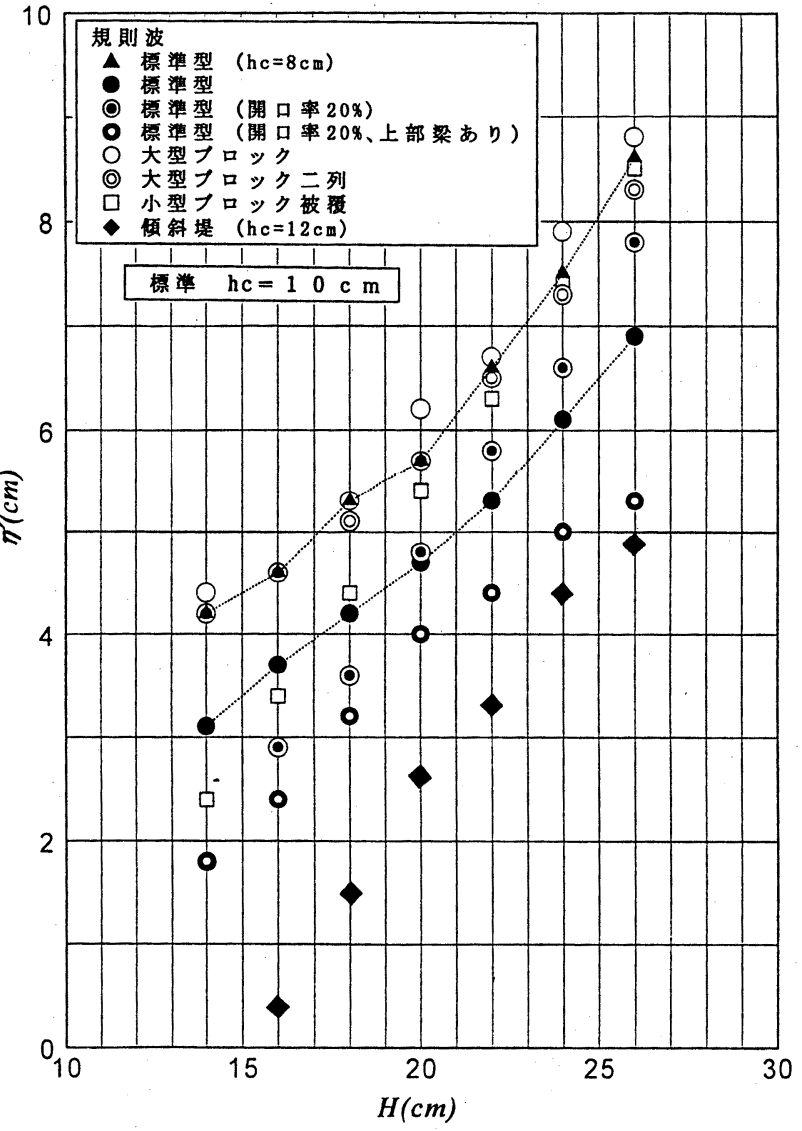

図-8 波の打ち上げ高さ 
大型ブロック設置型および小型ブロック被覆型は、 いずれも標準型の $h_{\mathrm{C}}=10 \mathrm{~cm}$ のケースに比べて、 打ち上げ高さは高くなっている。また、標準型の開 口率 $20 \%$ のケースは、波高が小さいと標準型よりも 低いが、波高が大きくなると逆に標準型よりもやや高 くなる。これに対し、上部梁付きのケースは標準型よ りも明らかに打ち上げ高さが低くなっている。緩傾斜 堤と高基混成堤を比較すると、緩傾斜堤のほうが打 ち上げ高さは小さいが、天端が $2 \mathrm{~cm}$ 高いことを考慮 して静水面からの打ち上げ高さで考えると、波高が $20 \mathrm{~cm}$ 以上のときには $h_{\mathrm{C}}=10 \mathrm{~cm}$ の標準型高基混成 堤と同じであり、上部梁付きのケースでは緩傾斜堤 よりも打ち上げ高さは低くなっている。

一方、図－9は飛沫の打ち上げ高さについて、図 -8と同様に示したものである。緩傾斜堤の場合、波 高が大きくなっても飛沫の高さは $30 \mathrm{~cm}$ で頭打ちとな っている。これに対して、高基混成堤の場合、飛沫 の高さは波高にほぼ比例して大きくなっており、特に 標準型の $h_{\mathrm{C}}=8 \mathrm{~cm}$ および $h_{\mathrm{C}}=10 \mathrm{~cm}$ ではかなり大皆 な值となっている。ただし、改良型についてはいず れのケースも標準型に比べて打ち上げ高さが低下し ており、直立部を改良した効果がみられる。特に、波

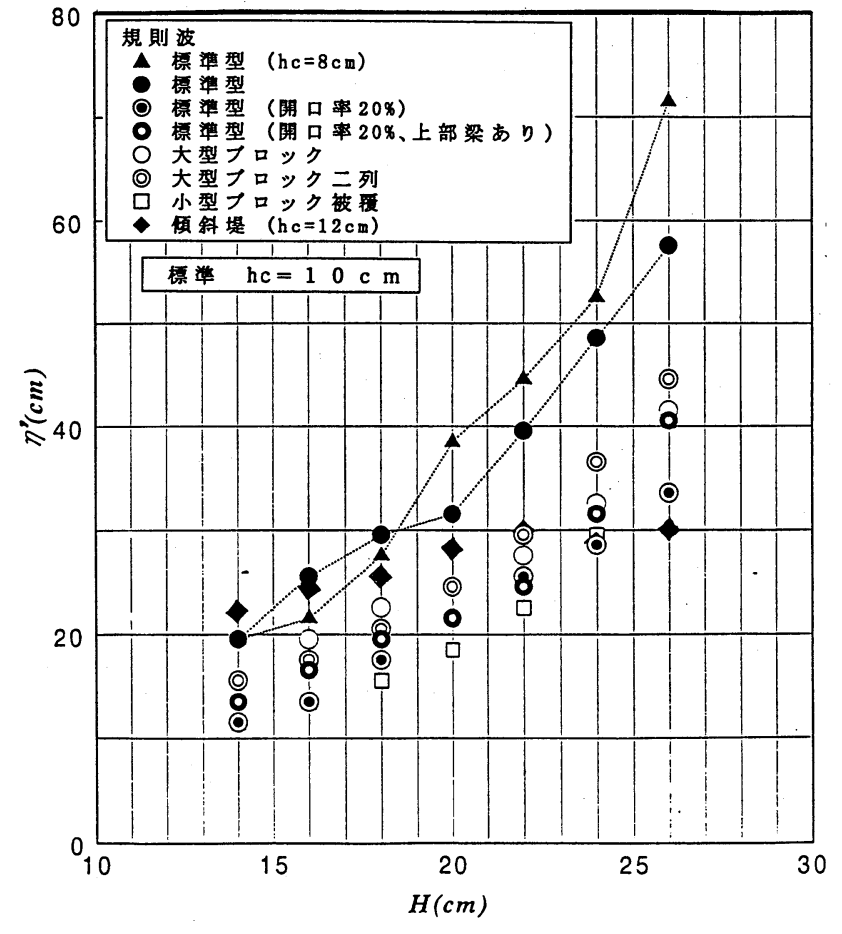

図-9 飛沫の打ち上げ高さ 高が $26 \mathrm{~cm}$ 以下のときには緩傾斜堤よりも小さな值となっている。

なお、高基混成堤では波の打ち上げ高さは遊水室後壁に近い位置で最大となるが、飛沫についてはおもに波 がスリットにぶつかるときに生じており、スリット前面に近い位置で打ち上げ高さが最大となることが多い。

\section{6. まとめ}

今回の研究により、消波型高基混成堤が従来の傾斜堤や緩傾斜堤に比べて越波特性に優れており、同じ許容 越波流量の場合、天端を低くできることが明らかになった。特に、スリットの開口率を $20 \%$ 、、スリット上部を梁で つなぐことにより、許容越波流量を満たすための相対天端高 $h_{\mathrm{C}} / H_{1 / 3}$ の值は 0.53 となり、通常の防波堤の天端高 よりも低くなることがわかった。ただし、上部梁を設けた場合、そこに作用する波力が問題となるため、部材強度に ついて検討する必要がある。なお、本文中では述べていないが、消波型高基混成堤の反射率は、今回の実験範 团では断面形状に関係なく $0.2 \sim 0.3$ 程度であり、マウンド斜面およびマウンド上での砕波によりエネルギーの大 部分が失われていることがわかる。

今後は、スリット上部梁付き型の越波特性および波力特性についてさらに検討を進めるとともに、被覆ブロック の安定性からみた最適断面の検討も行う予定である。なお、本研究の遂行にあたっては、運輸省第五港湾建設 局のご協力を得ており、特に、片平和夫設計室長および細川泰廣中部新国際空港調査室長には貴重な御助言 を得ている。ここに記して感謝の意を表する次第である。

\section{参考文献}

1) 合田良実・岸良安治:不規則波による低天端護岸の越波特性実験、港湾技研資料、No.242、1976、28p.

2) 高山知司・永井紀彦・西田一彦: 各種消波工による越波流量の減少効果、港湾技術研究所報告、第 21 巻第2号、 1982、pp.151-206.

3) 谷本勝利・原中祐人・高橋重雄・小松和彦・轟 正彦・大里睦男: 各種ケーソン式混成堤の反射・越波および波 力特性に関する模型実験、港湾技研資料、No.246、1976、38p.

4) 高橋重雄・鈴木高二朗・三浦裕信・斉藤祐一: 低天端型防波護岸の越波に関する一実験、海洋開発論文集、 Vol.11、1995、pp.193-198.

5) 下迫健一郎・高橋重雄・斉藤祐一・三浦裕信・H.Oumeraci : 消波型直立部を用いた高基混成堤の開発、海岸工 学論文集、第 43 巻、1996、pp.851-855. 